\title{
Authority and Attribution in the Sternhold and Hopkins Psalter*
}

\author{
REBECCA M. RUSH
}

Yale University

This essay addresses the vexed question of the genre of the Sternhold and Hopkins psalter by considering the framing of the psalms in the early editions printed in England and on the continent. It is undeniable that all of the producers of the Sternhold and Hopkins psalter were committed to the dissemination of Scripture in the vernacular and that many were concerned with approximating the hebraica veritas. But comparing the title pages, prefaces, and marginal notes included in the sixteenth-century versions of the psalter with those of contemporary prose translations reveals that the editors of the psalter distinguished the metrical psalms from prose translations by carefully marking them as the poetic products of particular authors. In calling on the names and titles of the versifiers as sources of the volume's authority, the editors of the Sternhold and Hopkins psalter forged an understanding of poetic authorship that would prove influential not only for later psalm translators but for English poets more generally. Indeed, this essay makes the case that the practices of authorial attribution employed in the psalters may have directly influenced the presentation of more celebrated verse anthologies like Tottel's Songes and Sonettes.

Cet article se penche sur la question controversée du genre du psautier Sternhold and Hopkins, en examinant lencadrement des psaumes dans les premières éditions anglaises et continentales. Il est indéniable que les éditeurs de ce psautier étaient engagés dans la diffusion des traductions en langue vernaculaire des Écritures et qu'ils cherchaient à s'approcher de la hebraica veritas. Toutefois, en comparant les pages titres, les préfaces, et les annotations marginales des différentes versions du XVIe siècle du psautier avec celles des traductions versions contemporaines en prose, on découvre que les éditeurs du psautier différencient les psaumes métriques des traductions en prose en les identifiant clairement comme le travail poétique d'auteurs spécifiques. En faisant reposer l'autorité de la publication sur les noms et les titres des poètes, les éditeurs du psautier Sternhold and Hopkins ont créé une vision de l'auteur poète qui allait non seulement avoir une grande importance pour les traducteurs suivants de psaumes, mais également pour les poètes anglais en général. En effet, cet article montre également que les pratiques d'attribution d'auteur dans les psautiers ont influencé directement la présentation d'anthologies de poésie plus réputées, telles que les Songes and Sonettes de Tottel.

\section{Tn a 1679 controversial pamphlet on public worship, nonconformist minister John Collinges argues that pastors should not be required to recite prayers "composed by other men confessedly not divinely \& immediately inspired." In}

\footnotetext{
* This essay has benefitted from the generous but rigorous criticism of many colleagues, but I am particularly indebted to Bruce Gordon and Joel Baden, who offered inspiration and guidance in the initial
} 
spite of his resolute opposition to prescribed prayers, Collinges defends the liturgical use of "Scriptural Psalms in the meeters of Sternhold and Hopkins." These psalms, he maintains, should not be considered "forms composed by fallible men" since they are equivalent to prose translations of Scripture: "We cannot understand how the metrical forms used by us in Singing make the Psalms we sing more Hopkins and Sternholds, then our Bibles are the Translators Bibles. For the meeter, it makes no alteration in sense, onely limits the number of Syllables in a pause for order in Singing."3 Since Collinges desires to minimize the role of fallible humans in the production of the liturgical psalms, he depicts the work of versification as a straightforward and innocuous enterprise: he imagines Sternhold and Hopkins simply dividing the words of the psalms into neat, uniform parcels of syllables that are more conducive to orderly singing. Because the divine contents-the original Hebrew "sense" of Scripture-are in no way altered by this re-packaging, Sternhold and Hopkins do not acquire ownership of the psalms; they are not "Hopkins and Sternholds" psalms but "Scriptural Psalms in the meeters of Sternhold and Hopkins." Unlike the prescribed liturgical forms contained in the Book of Common Prayer, Collinges asserts, the metrical psalms derive their authority from divine rather than human makers.

Although they may not share Collinges's sanguine belief in the compatibility of English metre and Hebrew sense, some scholars of early modern literature share the minister's view that Sternhold, Hopkins, and the other

stages of this project, and to David Kastan and the two anonymous readers whose thoughtful readings dramatically improved the final draft. I would also like to thank all of the participants in the 2014 Harvard-Yale Conference in Book History, whose presentations and probing questions helped clarify the stakes of the argument.

1. John Collinges, A reasonable account why some pious, nonconforming ministers in England judge it sinful for them to perform their ministerial acts, in publick, solemn prayer by the prescribed forms of others wherein several of their arguments are modestly propounded, opened and justified against pretended answers given to them, either by Ireneus Freeman, or Mr. Falconer, in his book entituled Liberitas ecclesiastica, or others. The strength also of the several arguments brought by them, for the lawfulness of forms to be used universally by ministers, in their publick ministrations, is fairly tried (London, 1679), B1r.

2. Collinges, F5r.

3. Collinges, A7r, F5v. Collinges's argument about Sternhold and Hopkins is a response to an argument made in a 1661 tract that the nonconformist preachers "praise God in prescribed forms made by Sternhold and Hopkins": Ireneus Freeman, $\Lambda$ ОГКН $\Lambda$ АТРЕIA, the reasonablenesse of divine service: or non-conformity to common-prayer, proved not conformable to common reason: in answer to the contrary pretensions of $H$. D. in a late discourse concerning the interest of words in prayer and liturgie (London, 1661), F1v. 
individuals who revised and completed their work desired to produce an accurate version of the psalter closely aligned to the prose translations of the day. Indeed, because their Elizabethan title pages advertise their connection to the Hebrew originals, the metrical psalms of Sternhold and Hopkins are often distinguished from the more "literary" psalm interpretations of writers like Wyatt, Gascoigne, and the Sidneys. David Norton, for example, separates metrical psalms into "versifications" and "poetifications," and argues that, despite their "blatantly literary form," versifications like Sternhold and Hopkins display a "strong anti-literary or anti-aesthetic element" and "were generally scorned by the literati." ${ }^{4}$ Ramie Targoff more sweepingly states that all "English metrical Psalters were regarded as texts of devotion and not also as poems throughout most of the sixteenth century." Targoff, like many scholars of devotional poetry, credits Philip Sidney with provoking a reconsideration of the psalms as poetry in England with his Defense of Poesie and metrically-varied psalms. ${ }^{5}$

In their meticulous examinations of metrical psalmody in early modern England, scholars like Rivkah Zim, Hannibal Hamlin, and Beth Quitslund have challenged this strict division between religious and literary texts. Zim points out that in "the sixteenth century, the art of poetry was considered an art of imitation"; therefore, we should not assume "that translation or imitation is an inferior, non-creative activity." As its title promises, Hamlin's book also brings "psalm culture" and "early modern English literature" closer together by highlighting the importance of the Davidic model for all sixteenth-century poets, who held the psalms "in high esteem, not only for their religious truths but for their literary quality as well." Hamlin depicts "translation as a literary endeavor" and demonstrates that early modern writers did not clearly distinguish translation from other forms of imitation like paraphrase or metaphrase. ${ }^{7}$

4. David Norton, History of the English Bible as Literature (Port Chester, NY: Cambridge University Press, 2000), 115.

5. Ramie Targoff, Common Prayer: The Language of Public Devotion in Early Modern England (Chicago: University of Chicago Press, 2001), 72-73; Philip Sidney, An apologie for poetrie (London, 1595); The Sidney Psalter: The Psalms of Philip and Mary Sidney, ed. Hannibal Hamlin (Oxford: Oxford University Press, 2009).

6. Rivkah Zim, English Metrical Psalms: Poetry as Praise and Prayer, 1535-1601 (Cambridge: Cambridge University Press, 1987), 7.

7. Hannibal Hamlin, Psalm Culture and Early Modern English Literature (Cambridge: Cambridge University Press, 2004), 2, 261, 8-12. 
Yet, despite their emphasis on the literary nature of all psalm translations, both Zim and Hamlin reinstate generic distinctions between the Sternhold and Hopkins psalter and the Sidney psalms. Although Zim notes that the Sidneys built on the conventions established by earlier metrical psalmists, she credits Sir Philip Sidney and the Countess of Pembroke with almost single-handedly "regenerat[ing] their contemporaries' expectations of psalms as poetry, and [making] English metrical psalms a suitable vehicle for contemporary devotional poetry." ${ }^{\prime}$ Hamlin makes the distinction between the Sidney and the common measure psalms even more apparent, organizing his book into separate sections on "metrical psalms intended for congregational singing in the worship services of the English Church" and on those "intended for serious reading as lyric poetry by the literati." The former, he argues in similar language to David Norton, "either eschewed aesthetic considerations entirely or clearly subordinated them to the transmission of the literal sense of the Scripture." Although the varied verse forms and polished diction of the Sidney psalms are certainly more appealing to modern scholars than the common metres of Sternhold and Hopkins, the Sidneys may have received undue credit for initiating a new understanding of the psalms as vehicles for aesthetic experimentation and individual artistry. Quitslund's thorough examination of Sternhold and Hopkins has begun to correct such assumptions about the popular intentions and anti-aesthetic qualities of the psalter by stressing its courtly origins. ${ }^{10}$ This study builds upon Quitslund's work on the Sternhold and Hopkins psalter as well as Zim's and Hamlin's more general claims about the literary nature of psalm translations by considering the ways that the Sternhold and Hopkins psalter advertises and celebrates the artistic endeavours of its contributors.

\section{Zim, 152}

9. Hamlin, 13, 144.

10. Beth Quitslund, The Reformation in Rhyme: Sternhold, Hopkins and the English Metrical Psalter, 1547-1603 (Burlington, VT: Ashgate, 2008). Ian Green also mentions the elite beginnings of the psalter, though he focuses on its later popular life. Ian Green, Print and Protestantism in Early Modern England (Oxford: Oxford University Press, 2000), 503. Robin Leaver, following Nicholas Temperley, has added to the discussion of the popularizing intentions of Sternhold by arguing that the ballad metre he adopted was not widely used at the time and that it only became popular as a result of Sternhold and Hopkins. Robin A. Leaver, Goostly Psalmes and Spirituall Songes: English and Dutch Metrical Psalms from Coverdale to Utenhove, 1535-1566 (Oxford: Oxford University Press, 1991), 119-20; Nicholas Temperley, The Music of the English Parish Church (Cambridge: Cambridge University Press, 1979), 1.26. 
While it is undeniable that all of the producers of the Sternhold and Hopkins psalter-from Sternhold himself to the printer John Day-were committed to the dissemination of Scripture in the vernacular and that many were concerned with approximating the hebraica veritas, the presentation of the text in all of its stages indicates that they derived much of their authority from the individual writers. Comparing the title pages, prefaces, and marginal notes included in the many versions of the psalter with those of contemporary prose translations reveals that the editors of the psalter distinguished the metrical psalms from prose translations by carefully marking them as the poetic products of particular authors. Though in the seventeenth-century Collinges would try to separate the psalms from their versifiers, the original editors do in fact depict the poems as "more Hopkins and Sternholds then our Bibles are the Translators Bibles." ${ }^{11}$ In fact, the practices of attribution employed in the psalters resemble those used in later verse anthologies like Tottel's Songes and Sonettes. In all of its versions, the psalter displays a combination of fidelity to the Scripture, concern for the spiritual edification of the listener, and recognition of the contributions made by individual human skill. This combination of concerns would prove formative not only for later psalm versifiers but for later English poets like Herbert and Milton who endeavoured to reconcile a scripturally-informed faith with the poetic enterprise.

\section{Background: the psalms of Coverdale and Crowley}

Two early English books of psalms, Miles Coverdale's Goostly Psalmes and sprituall songes drawen out of the holy Scripture (1535) and Robert Crowley's The Psalter of Dauid newely translated into english metre (1549), demonstrate two possible conceptions of metrical psalmody that would eventually be combined in the Genevan and Elizabethan editions of Sternhold and Hopkins. ${ }^{12}$ Miles Coverdale certainly understood the full range of ways that David's songs could be communicated in the vernacular, since, in addition to composing metrical psalms, he produced a prose version of the psalter in his 1535 Coverdale Bible

\section{Collinges, F5v.}

12. Robert Crowley, The Psalter of Dauid newely translated into Englysh metre in such sort that it maye the more decently, and wyth more delyte of the mynde, be reade and songe of al men. Wherunto is added a note of four partes, wyth other thynges, as shall appeare in the epistle to the readar (London, 1549). 
as well as a translation of Johannes Campensis's paraphrase of the psalms. ${ }^{13}$ As Robin Leaver has demonstrated, Coverdale's Goostly Psalmes are closely connected to his 1535 Bible since Coverdale's epistle to the psalms includes marginal biblical references (e.g., "Math. 4.c.") that correlate to the paragraph marks in the Coverdale Bible. ${ }^{14}$ Neither the psalms nor the Bible include Coverdale's name on the title page, but the prefatory epistles to the two works share the same title, "Myles Coverdale unto the Christen reader," which highlights their human origin. ${ }^{15}$ Despite many similarities between the two works, the titles of the volumes underscore the distinction between the biblical translation and the metrical psalmody. The elaborate title page of Coverdale's Bible, which the Short Title Catalogue (STC) conjectures was originally printed in Cologne, advertises the text's relationship to the inspired original. The title page border contains a series of images that trace the idealized transmission history of the Old and New Testaments, beginning with God himself, who is represented by the Hebrew tetragrammaton and a radiant ball of light at the top of the page. The title page announces in large script that the book is "BIBLIA, The Bible" itself and, in case the Latin and English titles were insufficient, adds the clarifying phrase, "that is, the holy Scripture of the Olde and New Testament." After illuminating the inspired nature of the text, the title goes on to indicate that the Scripture has been "faithfully and truly translated out of Douche and Latyn."16 Though Coverdale frankly admits in his preface as well as on the title page that he has no "knowledge and lernynge [...] in the tongues" of Greek and Hebrew and that he therefore worked from "sondrye translacions, not onely in latyn, but of the Douche interpreters," he nonetheless describes his work as a "diligent exercise of translatynge" parallel to the work of more knowledgeable scholars,

13. David Daniell, The Bible in English: Its History and Influence (New Haven: Yale University Press, 2003), 189; Miles Coverdale, A paraphrasis vpon all the Psalmes of Dauid, made by Iohannes Campensis, reader of the Hebrue lecture in the vniuersite of Louane, and translated out of Latine into Englysshe (London, 1539).

14. Miles Coverdale, Goostly psalmes and spirituall songes drawen out of the holy Scripture, for the co $[\mathrm{m}]$ forte and consolacyon of soch as loue to reioyse in God and his Worde (London, c. 1535), ${ }^{*} 1 \mathrm{v}$; Leaver, 67. 15. Miles Coverdale, Biblia the Bible, that is, the holy Scripture of the Olde and New Testament, faithfully and truly translated out of Douche and Latyn in to Englishe (Cologne?, 1535), *4v; Coverdale, Goostly, ${ }^{*} 1 \mathrm{v}$.

16. All of the English editions of the Bible dropped the allusion to Dutch and Latin in the title, simply stating that the Bible had been "faithfully translated in Englysh." STC 2063.3, 2064, 2065. 
and repeatedly refers to his book as a faithful and reliable "translacyon" of the Holy Bible. ${ }^{17}$

In contrast to the title page of Coverdale's Bible, with its elaborate depictions of scriptural transmission and its claim to contain the "Bible, that is, the holy Scripture" itself, the title page of Goostly psalmes is strikingly modest, simply stating that the songs have been "drawen out of the holy Scriptures." The past participle seems to indicate some distance from the text itself and to highlight the labour involved in converting the biblical text into English metre. Significantly, the verb would again be used in the titles of the first two publications of Sternhold's psalms as well as in those of the many verse paraphrases inspired by Sternhold's work and produced from 1549 to $1553 .{ }^{18}$ This difference in title suggests that Coverdale believes that his songs, while "grounded on Gods worde," are nonetheless "not the texte," as he puts it in his paraphrase. ${ }^{19}$

Coverdale more explicitly marks his song book as an artistic rather than a linguistic enterprise by including an envoy, traditionally associated with poetry, on his title page:

Go lytle boke, get the acquaintuance

Amonge the louers of Gods worde

Geue them occasion the same to auaunce

And to make theyr songes of the Lorde

That they may thrust vnder the borde

All other balettes of fylthyness

\section{Coverdale, Biblia the Bible, ${ }^{\star} 4 \mathrm{v}-{ }^{\star} 5 \mathrm{r}$.}

18. For example, William Hunnis, Certayne psalmes chosen out of the psalter of Dauid, and drawen furth into Englysh meter (London: 1550); John Hall, Certayne chapters of the prouerbes of Salomon drawen into metre (London, 1550); Frances Seager, Certayne Psalmes select out of the Psalter of Dauid, and drawen into Englysh metre (London,1553). Ramie Targoff mentions the implication of "artful labor" in the titles of sixteenth-century psalters and recognizes that this indicates an acknowledgement that something besides "strict translation" is at work, though, she insists, it is still not "poetic production of lyric"; see Targoff, 72-73. For discussion of the rage for metrical Scripture from 1549-1554, see Leaver, 137-39 and Quitslund, 59-109.

19. Coverdale, Goostly, ${ }^{\star} 3 \mathrm{r}$; Coverdale, A paraphrasis, A2r. Zim uses Coverdale’s distinction between paraphrase and the text itself as a structuring distinction for her account of early modern imitatio and the Psalms. Hamlin is right to point out that the various words for translation in the period are more slippery than Zim acknowledges, but her dichotomy is nevertheless helpful. Zim, 12. Hamlin, 8-9. 
And that we all with one accorde

May geue ensample of godlynes. ${ }^{20}$

As John S. P. Tatlock has shown, the tradition of sending off one's book with a phrase like "Go, little book" can be traced back to Ovid and Martial, but the most famous example is Chaucer's "Go lytell boke" direction at the end of Troilus and Criseyde, where he sends off his book, prays that God will let him live long enough to write a comedy, and instructs his book to humble itself before the "poesy" of Virgil, Ovid, Homer, Lucan, and Statius. ${ }^{21}$ Although Chaucer's work is not explicitly religious in theme, his envoy combines patent concern for the poetic status of the work with the author's desire for divine aid. Langland's imitation of Chaucer in his poetic account of the life of the Virgin Mary is closer to Coverdale's version since it also instructs the book to seek acceptance among kindly readers:
Go litell boke / and submitte the
Unto all them / that the shall rede
Or here / prayenge hem for charite
To pardon me of the rudehede
Of myne enpryntynge / nat takynge hede
And if ought be done to theyr pleasynge
Saye they these balades folowynge. ${ }^{22}$

The fact that Coverdale addresses his envoy explicitly to the "louers of Gods worde" distinguishes it from the envoys of Chaucer and Langland, but by using a trope associated with "poesy," both secular and religious, Coverdale signals that his volume should also be considered a work of human art. His "songes of the Lorde" will drive out the "balettes of fylthyness" not because the two are

\section{Coverdale, Goostly.}

21. John S. P. Tatlock, “The Epilog of Chaucer's 'Troilus,” Modern Philology 18.12 (April 1921): 625-59; Geoffrey Chaucer, The noble and amerous aucyent hystory of Troylus and Cresyde, in the tyme of the siege of Troye. Co[m]pyled by Geffraye Chaucer (London, 1517), z5v.

22. John Lydgate, This boke is compyled by Dan Iohn Lydgate monke of Burye, at the excitacion [and] styrynge of the noble and victorious prynce, Kynge Henry the fyfthe, $i[n]$ the honoure glorie [and] reuerence of the byrthe of our moste blessed Lady, mayde, wyfe, [and] mother of our lorde Iesu Christe (London, 1531), 2H5r. 
fundamentally different in kind, but because he employs the same poetic and musical means to a more spiritual end: as he puts it in the title of the volume, the songs are "for the comforte and consolacyon of soch as loue to reioyse in God and his worde."

Robert Crowley's psalter, published fourteen years later, also appeals to the passions of readers and listeners, hoping that it will "moue" them "to delyte in the readynge and hearynge of these Psalmes."23 Yet Crowley draws attention to his scholarly methodology in the epistle addressed, like Coverdale's, "To the Christian Reader." A fervent Protestant who published editions of Wyclif, Tyndale, and Langland in addition to his own polemic and verse, Crowley forthrightly declares that he has "folowed" the translation of "Leo Judas" to whom, he says, God revealed "those thynges that were vnknowne to them that before hym translated the Psalter out of the Ebrue." ${ }^{24}$ In addition to advertising his consultation of a recent work of biblical scholarship, the 1543 Zurich Latin Bible, Crowley distinguishes his volume from Coverdale's song book by calling his work a "translation" in both the preface and the title ("newely translated into Englysh metre") and declaring that he has "made open and playne, that whiche in other translations, is obscure \& harde." ${ }^{25} \mathrm{He}$ admits that his translation may contain errors, but cautions that emendations can only be supplied by those who are "better learned" in languages than he. Those who are not linguists but who "chance to confer thys translation" with others and notice "that they disagre" should not hastily "dislyke either of them, but first consult men of learnynge \& iudgement in the knowledge of tonges." ${ }^{26}$ Although Crowley's translation is twice-removed from the Hebrew, he endeavours to establish its authority on the

\section{Crowley, ${ }^{* *} 1 \mathrm{v}$.}

24.Crowley, ${ }^{*} 2$ r; see STC 25588, 24469, 19907, 6082, 6083, 6086, 6088, 6094. John King makes the case that, in contrast to later Puritans, the non-conformist Crowley viewed poetry as a powerful tool of reform; see King's “Robert Crowley: A Tudor Gospelling Poet," YES 8 (1978): 220-37.

25. For a discussion of Jud's translation and its relation to the Hebrew, see Josef Eskhult, "Latin Bible Translations in the Protestant Reformation: Historical Contexts, Philological Justification, and the Impact of Classical Rhetoric on the Conception of Translation Methods," Shaping the Bible in the Reformation: Books, Scholars, and Their Readers in the Sixteenth Century, ed. Bruce Gordon and Matthew McLean (Leiden: Brill, 2012), 178-79. Quitslund also connects the Latin dedication to Owen Oglethorpe, president of Magdalen College, Oxford, to Crowley's pretensions to scholarliness, noting that Oglethorpe's conservative religious views make him an otherwise strange choice. Quitslund, 91.

26. Crowley, ${ }^{* *} 2 \mathrm{r}$. 
firm foundation of the original text, echoing Coverdale's preface to his prose translation of the Bible rather than to his metrical psalter. The two ideas of metrical psalmody represented by Coverdale's and Crowley's volumes would shape the history of the Sternhold and Hopkins psalter, which eventually combined Coverdale's presentation of his volume as an artistic collection with Crowley's concern for scholarly, linguistic accuracy.

\section{Thomas Sternhold, groom of the king's majesty's robes}

The title page of the first printed version of Sternhold's psalms, published sometime between February 1547 and August 1549, proudly announces its author's name and his connection to the court of young King Edward VI: Certayne Psalmes chose[n] out of the psalter of Dauid, and drawe[n] into English metre by Thomas Sternhold grome of ye kynges Maiesties Roobes. ${ }^{27}$ By placing the name and rank of their English versifier alongside the name of their original producer, the title page suggests that Sternhold is engaged in a literary activity comparable to that of David. The title specifies the nature of this literary activity by reusing but redefining Coverdale's past participle, "drawen." While Coverdale's psalms were "drawen out of the the holy Scripture," Sternhold's nineteen psalms were deliberately "chosen out of" David's psalter and then "drawen into English metre" (my emphasis). The new use of the verb "draw" depicts metrification not only as a laborious, but even as a violent enterprise in which the Hebrew psalms must be dragged or stretched into their new English form..$^{28}$

The title would be straightforwardly imitated in the December 1549 edition of Wyatt's penitential psalms, the title of which indicates that the psalms

27. Thomas Sternhold, Certayne Psalmes chose[n] out of the psalter of Dauid, and drawe[n] into English metre by Thomas Sternhold grome of ye kynges Maiesties Roobes (London, ca. 1547-49). Because it is dedicated to "our soveraigne Lorde Kynge Edward the.vi," the first version must have been printed after Edward's coronation in February 1547. The first version seems to have been printed before Sternhold's death in August 1549 since the title of the second version declares that it contains the psalms that the "late grome of [the] kinges Maiesties Robes didde in his life time draw into English Metre." The printer of both versions, Edward Whitchurch, was one of Sternhold's executors. See Sternhold's will, TNA: PRO, PROB 11/32/512 sig. 37.

28. Donne used the verb to describe the violent restraint metrical form imposes on human passions: the speaker in "The Triple Fool" says, "I thought, if I could draw my paines, / Through Rimes vexation, I should them allay"; see Poems, by J. D. With elegies on the authors death (London, 1633), Dd2v. 
were "drawen into englysh meter by Sir Thomas Wyat knyght."29 In addition to his renditions of the psalms, Wyatt's volume includes meditations on each psalm marked with the heading "The Auctor." Although Sternhold's volume does not provide authorial commentary on each psalm, the title page of his collection similarly represents him as an auctor in both its earlier sense of an authority figure who lends legitimacy and gravitas to the text and in its later sense of a composer of a written work. This preoccupation with the name and rank of the author distinguishes Sternhold's volume not only from Crowley's "translation" but also from Coverdale's more poetic book of songs, which only included his name in the heading of the epistle to the reader.

Indeed, Sternhold's dedication to King Edward places the psalms firmly within a courtly circle where verse functioned both as a tribute to the monarch and a display of individual skill. Sternhold, like many of his Edwardian contemporaries, added to this another function: to demonstrate and exercise his devotion to a scripturally-grounded faith. This additional religious function does not, however, efface the traditional courtly and poetic function more commonly associated with the love poetry of the period. Like the allusion to Sternhold's official position on the title page, the dedication advertises the courtly standing of the poet by revealing that he had already sung his psalms to Edward and that the king had "take[n] pleasure" in them. Sternhold hopes that the king will continue to demonstrate his approval of Sternhold's efforts by reading the psalms privately and commanding their public performance. ${ }^{30}$ Sternhold, like the other courtier poets and musicians of his day, originally circulated his verse orally and perhaps in manuscript within the confines of the royal household. There is no reason to think that members of the court would have distinguished Sternhold's work from other courtly endeavours because of its scriptural basis. The decision to print the volume does indicate that Sternhold and his publisher, Edward Whitchurch, saw a wider audience for the metrical psalms, but even the print version is carefully marked as the product of a court culture where secular and religious verse circulated together.

For all his humility about the "grossenesse" of his wit and the modesty of his enterprise, in his dedication to the king, Sternhold represents his

29. Thomas Wyatt, Certayne psalmes chosen out of the psalter of Dauid, commonlye called thee. vii. penytentiall psalmes, drawen into englyshe meter by Sir Thomas Wyat knyght, wherunto is added a prolage of [the] auctore before euery psalme, very pleasau[n]t \& profettable to the godly reader (London, 1549).

30. Wyatt, Certayne psalmes, A3r. 
versification of the psalms as a form of spiritual work by employing biblical metaphors about bearing fruit and harvesting wheat. He explains that he was inspired to compose and present his psalms because he did not want to appear "utterly ydle and barraine, beyng warned" by the "example of the drye fygg tree." The example Sternhold alludes to comes from a story in Matthew and Mark in which Christ discovers a fruit tree on the side of the road that has leaves but no fruit; as a punishment for this barrenness, Christ curses the tree so that it withers and dries from the roots. ${ }^{31}$ Sternhold's reference to this portrayal of Christ as an exacting master echoes Protestant discourses that depict good works as products and marks of faith. The Edwardian book of homilies, for example, declares that "the liuely and true faithe of a Christian man [...] causeth not a man to be idle, but to be occupied in bringyng furthe good workes" and that "faithefull men, (puttyng awaye all feare of aduersitie) wyll shewe furthe the fruite of their good workes." ${ }^{32}$ By echoing Protestant discourse about faith and works, Sternhold suggests that his metrical labour testifies to his lively and true faith. He also employs an extended harvest metaphor to portray himself as a figure like "Ruth, the Moabite," who comes behind to "gather a fewe eares of corne after the reapers" while others bring in great handfuls of wheat. As he expands upon the metaphor, it becomes clear that the "reapers" are the ordained clergy, who, rather than forbidding "laye men to gather and lease in the lordes harvest" as their Catholic predecessors did, actually drop some of the wheat so that industrious laypeople can gather it. The comparison allows Sternhold to maintain the distinction between clergy and laity while expanding the definition of doing the lord's work to include enterprises that take place beyond the church walls. By connecting the literary enterprise of drawing the psalms into English metre with the spiritual labour required by the great taskmaster, Sternhold lays the groundwork for later poets like Herbert and Milton who struggled to reconcile poetic and religious work.

Although Sternhold describes himself as a labourer in God's fields, he is careful to distinguish his work from that of the translator, maintaining a careful balance between claiming that his psalms derive from their Hebrew forebears and acknowledging their distance from the Scripture itself. He seems to have

31. Matthew 21:19-21; Mark 11:13, 20-24; there is a related story in Luke 13:6-9 about a man who cuts down a fig tree that will not bear fruit.

32. Certayne sermons, or homelies appoynted by the kynges Maiestie, to be declared and redde, by all persones, vicars, or curates, euery Sondaye in their churches, where they haue cure (London, 1547), hlv, f4r. 
consulted multiple sources in his composition of the psalms-various versions of Coverdale's psalms and the Latin of the Vulgate-but he does not, as Crowley does, draw attention to his work as a scholarly enterprise in line with the translation work occurring in England and on the continent. In fact, he underscores the distinction between his metrical work and the prose psalter, telling the king, "as you haue the Psalme it selfe in youre mynde, so ye maye iudge myne endeauoure by your eare." ${ }^{33}$ It is unlikely that Sternhold is crediting Edward VI with knowledge of the Hebrew original, so the "Psalme it selfe" must refer to a prose version in Latin or English. Sternhold's renditions, then, are close enough to the songs of David that they can be judged in comparison to a prose version but they are decidedly not and do not to pretend to be the psalms themselves. Sternhold's declaration that his works are not the psalms suggests that they are courtly poems tied to a specific maker rather than scholarly translations of the text.

Although Sternhold promises in his dedication to metrify the "residue" of the psalms if his "labor" proves "acceptable" to Edward, he seems to have produced only eighteen more psalms before his death in August 1549. ${ }^{34}$ Sternhold's thirty-seven psalms, along with seven psalms by John Hopkins, were published in late 1549 as Al such Psalmes of David as Thomas Sternehold late grome of the the kinges Majesties Robes, didde in his life time draw into English metre. In this expanded version of the volume, the emphasis on Sternhold's authorship becomes even more explicit. The new title page ignores Hopkins's contribution but accentuates Sternhold's: his name occupies an even more prominent place than it did in the original publication and is even printed in larger letters than the name of David. ${ }^{35}$ In addition, Sternhold's portion of the text is emphatically separated from Hopkins's; Sternhold's section concludes with the word "FINIS," surrounded by manicules for accentuation, and a declaration that "Here end the psalmes drawen into Englishe Metre, by M. Sternholde." 36 The modes of attribution employed in this 1549 psalter may have influenced a more widely known verse anthology produced eight years later, Richard Tottel's Songes and sonettes, written by

33. Certayne psalmes, A3r; Quitslund, 158.

34. Certayne psalmes, A3r. TNA: PRO, PROB 11/32/512 sig. 37.

35. Al such psalmes of Dauid as T. Sternehold didde in his life time draw into English metre (London, 1549).

36. Al such psalmes, G2r. 
the right honorable Lorde Henry Haward late Earle of Surrey, and other. ${ }^{37}$ Like the Sternhold psalm book, the title page of Songes and sonnettes invokes the name and official title of a "late" author. Within the pages of the volume, the contributions of each poet are distinguished in a similar manner to the psalm volume: the names "SVRREY" and "T.WYATE the elder," like that of "M. Sternholde," are printed at the end of the sections containing their poems. ${ }^{38}$ The Wyatt portion of the volume is then followed by sections headed "Songes and Sonnettes of vncertain auctours" and "Songes written by N. G." ${ }^{39}$ Whether or not the Edwardian psalm compilation directly influenced the Marian anthology of lyrics, the similarities between the attributions in the two volumes suggest that they had a shared desire to advertise and label the productions of courtly poets in order to capitalize on their authority and, perhaps, in order to reward their metrical endeavours with public recognition.

If anything, the 1549 Sternhold and Hopkins volume more clearly designates the contributions of each writer than does Tottel's miscellany since each section is prefaced with a note by the author: Sternhold's original dedication to the king remains in the expanded volume, and John Hopkins prefaces his contribution with a signed note "To the Reader." In his preface, Hopkins insists that he does not intend for his psalms to "be fathered vpon the dead man, and so through his estimacion" be "more highly esteemed." ${ }^{40}$ The paternal metaphor underscores the strong sense that Sternhold is the auctor of the psalms and that their worth stems from his name and reputation. Hopkins goes on to describe Sternhold as the consummate metrical craftsman: "as touching the Metre," he notes, the additions can in no way compare to Sternhold's "moste exquisyte dooyngs." The idea that the psalms derive their authority from Sternhold's name and his chosen metre would become a permanent part of the psalter, since "psalms," "Sternhold," and "metre" are the only words that were included in the title of every version of the psalter. Despite the fact that in this volume Hopkins claims that his own writings are only meant to "fyll up a place," his name would eventually join Sternhold's on the title page in John Day's 1562

37. Songes and sonettes, written by the right honorable Lorde Henry Haward late Earle of Surrey, and other (London, 1557).

38. Songes and sonettes, E2v, N1v.

39. Songes and sonettes, N2r, Fr1r.

40. Al such psalmes, G2v. 
version of the psalter and the two names would appear in every subsequent edition.

\section{The psalter in exile}

Although the Sternhold and Hopkins psalter sold remarkably well during Edward's reign-Quitslund notes that the fourteen editions of Certayn psalmes and $\mathrm{Al}$ such psalmes make it the most reprinted text in Edwardian England besides official ecclesiastical publications-publication of the volume ceased shortly after the accession of Mary. Its primary printer, Edward Whitchurch, who also printed the Matthew Bible, the Great Bible, and the Book of Common Prayer during Edward's reign, was exempted by name from Queen Mary's October 1553 coronation pardon. ${ }^{41}$ No publications appear under Whitchurch's name after 1553, but it is unclear whether he remained in England or fled to the continent. ${ }^{42}$ The Sternhold and Hopkins psalter certainly travelled with the Marian exiles to the continent, where the psalms began to be used as liturgical texts. ${ }^{43}$ A volume containing the forty-four psalms of Sternhold and Hopkins, along with eight additional psalms by William Whittingham and an unknown writer, a collection of prayers, and a catechism, was published in Wesel sometime between 1554 and $1556 .{ }^{44}$ In 1556, Jean Crespin, who had recently printed his well-known Protestant martyrology, Le Livre des Martyrs, published the forme of prayers and ministration of the sacraments, \& $r$ vsed in the English Congregation at Geneua: and approued, by the famous and godly learned man, Iohn Caluyn, which included One and fiftie Psalmes of Dauid in Englishe metre, whereof. 37. were made by Thomas Sterneholde: a[n]d the rest by others. The psalter includes the same psalms as the Wesel volume (excluding the single anonymous psalm), but the Sternhold and Hopkins psalms have been amended and a wealth of musical and textual aids have been added to the text: it is the

41. STC 2066, 2070, 16290; Tudor Royal Proclamations, ed. Paul L. Hughes and James F. Larkin (New Haven: Yale University Press, 1969), 2.16.

42. Whitchurch married Thomas Cranmer's widow, Margaret, sometime after the archbishop's execution in 1556, but it is unknown when or where they married. See Whitchurch's Will, TNA: PRO, PROB 11/45; Diarmaid MacCulloch, Thomas Cranmer: A Life (New Haven: Yale University Press, 1996), 609-11.

43. Quitslund, 111-53.

44. Psalmes of Dauid in metre (Wesel: ca. 1554-56); Quitslund, 126; Leaver, 199. 
first edition to include musical notations, prose arguments for each psalm, marginal glosses, and verse numbers. ${ }^{45}$

These changes and additions have been attributed to William Whittingham, who headed a group of English exiles in Geneva that split off from the congregation in Frankfurt. ${ }^{46}$ During his time in Geneva, Whittingham produced a translation of the New Testament, published by Conrad Badius in 1557, and contributed significantly to the translation of the Geneva Bible. ${ }^{47}$ He may also have been responsible for a 1557 prose psalter that revised Coverdale's Great Bible text. ${ }^{48}$ Noticeably, the titles of all of these works advertise the fact that Whittingham has consulted the original languages: the extended title of the One and Fifite Psalmes announces that it has been "conferred with the Hebrewe, and in certaine places corrected, as the text and sens[e] of the Prophete required." ${ }^{49}$ In his general preface to the Form of Prayers, Whittingham explains his methodology in revising the work of Sternhold and Hopkins, stressing the fact that he has always preferred the divine "meanyng" over the particular words written by "any man." Therefore,

we thought it better to frame the ryme to the Hebrewe sense, then to bynde that sense to the Englishe meter and so either altered for the better in suche places as he had not attayned vnto, or els where he had escaped

45. Quitslund, 142-43.

46. William Whittingham, A brieff discours off the troubles begonne at Franckford in Germany Anno Domini 1554 Abowte the booke off off [sic] common prayer and ceremonies, and continued by the Englishe men theyre/ to thende off $Q$. Maries raigne, in the which discours, the gentle reader shall see the very originall and beginninge off all the contention that hathe byn, and what was the cause off the same (Heidelberg, 1574); for further information on Whittinham's life and ministry, see Christina Hallowell Garrett, The Marian Exiles: A Study in the Origins of Elizabethan Puritanism (Philadelphia: University of Pennsylvania Press, 1938), 327-30 and Dan G. Danner, Pilgrimage to Puritanism: History and Theology of the Marian Exiles at Geneva, 1555-1560 (New York: Peter Lang, 1999), 43-47.

47. The Nevve Testament of our Lord Iesus Christ. Conferred diligently with the Greke, and best approued translations. With the arguments, as wel before the chapters, as for euery boke \& epistle, also diuersities of readings, and moste proffitable annotations of the harde places: whereunto is added a copious table (Geneva: 1557).

48. The psalmes of Daiud translated according to the veritie and truth of th'Ebrue, wyth annotacions most profitable (Geneva, 1557); Quitslund, 159-60.

49. Zim argues that there is no real basis to the claim that the editor has conferred with the Hebrew. Zim, 141. 
part of the verse, or some tymes the whole, we added the same: not as men desyrous to finde fautes, but onely as suche which couuete to hyde theym, as the learned can iudge. ${ }^{50}$

Like the participles in the titles of earlier psalters, Whittingham's verbs reveal much about his theory of versification. He recognizes the violence involved in bringing together Hebrew psalms and English metre, but he chooses to do violence to the poetry by "fram[ing] the rhyme to the Hebrew sense" rather than distorting the Hebrew by "bynd[ing]" it to the oppressive dictates of English rhyme and metre. Whittingham prioritizes the claim to linguistic precision in the title and prefatory material, endeavouring to translate Sternhold's courtly psalms into versifications much closer to the "psalms themselves."

In practice, though, Whittingham's methodology does not differ so significantly from Sternhold's as he claims. As Zim has noted, many of Whittingham's modifications, such as his addition of alliteration, could only have been motivated by stylistic rather than linguistic considerations. ${ }^{51}$ At times, his revisions do bring Sternhold's songs closer to the Hebrew, such as when he alters the opening of psalm 5 from "Ponder my wordes, O Lorde above" to "Incline thyne eares vnto my wordes, o lord," perhaps to acknowledge that the Hebrew verb for listening derives from the same root as the word for ear. ${ }^{52}$ Oftentimes, however, Whittingham attempts to bring Sternhold's words closer to the Hebrew sense, only to find that he too is bound by metre and rhyme. In the ninth psalm, for example, Sternhold amplifies the text to stress his awe at God's works, adding that they are "unsearchable of me." ${ }^{33}$ In order to erase this authorial commentary, Whittingham must rework the entire stanza, since "me" is the final rhyme in the Sternhold version. In reforming the stanza, however, the Geneva reviser adds amplifications of his own: the Hebrew word "heart" becomes "heart and mouth," the single Hebrew verb for praise becomes "sing laude and praise," and the psalmist not only "speak[s]" of God's wondrous works but promises he will "them declare alwaies." ${ }^{4}$ Thus, internal evidence does to some extent support

50. The Forme of prayers, 21.

51. Zim, 141; see also Quitslund, 158.

52. Al such, A7v; One and fiftie Psalmes, A6v.

53. Al such, B3v.

54. One and fiftie Psalmes, B4r. 
the title-page claims to scholarly precision, but it also reveals that Whittingham sometimes sacrificed proximity to the Hebrew for the sake of rhyme and metre.

Whittingham strengthens the connection between the metrical psalter and biblical scholarship by providing marginal notes as well as verse numbers for easy cross-referencing. ${ }^{55}$ Although the notes are much sparser than in the Geneva Bible, they perform similar functions, sometimes pointing to related verses in other biblical books, sometimes summarizing the meaning of a text, and sometimes attempting to provide access to the Hebrew (e.g., the gloss on "bondes" in psalm 2 is "In heb. great ropes or cables"). ${ }^{56}$ These new trappings of biblical scholarship in the 1556 psalter have led scholars like Quitslund to argue that Whittingham, unlike Sternhold, sees the metrical psalms "as self-sufficient translations." ${ }^{57}$ Indeed, Whittingham's Genevan psalter certainly seems to extend beyond even Crowley's "translation" in its aspiration to resemble the original text and contemporary prose translations. ${ }^{58}$

While the Genevan version of the psalter clearly derives much of its authority from the Hebrew verity, Whittingham does not eliminate the attribution to individuals and the acknowledgement of their artistic endeavour characteristic of the earlier editions. The title page notes that thirty-seven of the psalms were "made by Thomas Sternehold: and the rest by others," echoing the titles of earlier English editions but changing the verb used to describe Sternhold's work. If anything, the new verb, "made," suggests a more artistic and poetic enterprise than "drawen into Englysh meter," especially since, as writers of defenses of poetry were keen to point out, the word poesy derives from the Greek for making. ${ }^{59}$ Thus, for all Whittingham's attempts to bring the metrical psalms closer to the Hebrew, they are still presented as the productions not simply of David but of individual Englishmen. In contrast, the prose

55. Quitslund notes that the psalter, not the Whittingham New Testament or the Geneva Bible, actually is the first printed English Scripture to include verse numbers; Quitslund, 143.

56. One and fiftie Psalmes, A3r.

57. Quitslund, 158; see also Leaver, 228.

58. Quitslund argues that the apparatus "encourages the reader to view them as primarily the Word of God rather than as simply hymns"; as will become more apparent below, I do not think that the Genevan psalter presents the metrical psalms as the Word of God full stop, but indicates that the poetic effort creates some distance from the original. Quitslund, 190.

59. George Puttenham, The Art of English Poesy, ed. Frank Whigham and Wayne A. Rebhorn (Ithaca: Cornell University Press, 2007), 93; Philip Sidney, Apologie, C1r. 
versions of the Scripture that Whittingham and his fellow Genevans produced in the same period are consistently called translations. Whittingham's 1557 prose psalter is titled The psalmes of Dauid translated accordyng to the veritie and truth of th'Ebrue, wyth annotacions moste profitable, presaging the claim on the title page of the 1560 Geneva Bible that the book has been "Translated according to the Ebrue and Greeke, and conferred with the best translations in diuers languages." ${ }^{60}$ Perhaps more importantly, these Genevan prose versions, unlike Coverdale's Bible, never name their contributors. The absence of their names suggests that the work of the translators is immaterial, as if they are mere amanuenses of the Holy Spirit, transmitting the word straight from the fonts of Hebrew and Greek. All of these differences in presentation make it clear that the Genevan editors, perhaps precisely because of their dedication to the Hebrew verity, desired to distinguish the metrical psalter from prose Scripture, marking it as the work of human hands.

Another innovation in the apparatus of the text accentuates the idea that the psalms derive their form and part of their authority from their human makers: unlike in the Edwardian and Wesel psalters, each individual psalm of Sternhold and Hopkins is marked with initials specifying the author. This addition to the text may have been the work of printer Jean Crespin, since the psalms of Marot and Beza are similarly distinguished with initials in his 1551 volume, Pseavmes octantetrois de Dauid, mise in rime Francoise. ${ }^{61}$ Whittingham's initials do not appear on his contribution in this 1556 volume, but they do in the expanded 1558 version. As Zim has noted, the removal of the prefaces by Sternhold and Hopkins and the elimination of the distinct divisions between their sections certainly produce a more "uniform collection in a single numerical sequence." Yet Zim also argues that the psalms in the Geneva volume are more "anonymous" and the volume is no longer presented as an "anthology of

60. The psalmes of Dauid translated accordyng to the veritie and truth of th'Ebrue, wyth annotacions moste profitable (Geneva, 1557); The Bible and Holy Scriptures conteyned in the Olde and Newe Testament. Translated according to the Ebrue and Greke, and conferred with the best translations in diuers languges. With moste profitable annotations vpon all the hard places, and other things of great importance as may appeare in the epistle to the reader (Geneva, 1560).

61. Pseaumes Octantetrois de Dauid, mise in rime Francoise par Clement Marot et Theodore de Beze. Imprime par Jean Crespin a Geneve 1551 (New Brunswick, NJ: Friends of the Rutgers University Library, 1973). 
the works of different individual authors." ${ }^{62}$ The addition of authorial initials next to each psalm weakens her claim: although the attribution to individual authors is less dramatic than it was in the Edwardian versions, it is more pervasive. Readers cannot turn to a single page in the volume without being reminded that each psalm was versified by a particular individual. In fact, this feature of the psalter may have been imitated in Elizabethan verse miscellanies. While the 1557 Songes and Sonettes attributed poems by dividing the volume into sections, several miscellanies produced in the 1570s and 1580s, including The paradyse of daynty deuises (1576) and A handefull of pleasant delites (1584), mark each individual poem with the initials of the author. ${ }^{63}$ Although the similarity does not prove that the editors of these volumes were inspired by the psalter, it is striking that this alteration in miscellany attributions occurred after wide dissemination of Sternhold and Hopkins in the 1560s and 1570s. Like the 1549 version of the psalm book, the Genevan versions have characteristics that resemble verse anthologies as much as biblical translations.

\section{The Elizabethan psalter}

Although Whittingham remained in Geneva until May 1560, many of the Marian exiles returned to England in the year following Elizabeth's accession to the throne in November 1558, and some seem to have brought the Geneva form of prayers and psalter along with them for they were soon published by London printers eager to resume their publication of Protestant religious texts. The Stationers' Registers record some contention between John Day and his former partner William Seres about the printing of metrical psalters. Seres paid for a license "to prynte $[. .$.$] psalmes in metre noted and proverbis in metre," probably versions of$

62. Zim, 142.

63. The paradyse of daynty deuises aptly furnished, with sundry pithie and learned inuentions: deuised and written for the most part, by M. Edwards, sometimes of her Maiesties chappel: the rest, by sundrylearned gentlemen, both of honour, and woorshippe. viz. S. Barnarde. E. O. L. Vaux. D. S. IasperHeyvvood. F.K. M. Bevve. R. Hill. M. Yloop, vvith others (London, 1576); A handefull of pleasant delites, containing sudrie new sonets and delectable histories, in diuers kindes of meeter. Newly deuised to the newest tunes that are now in vse, to be sung: euerie sonet orderly pointed to his proper tune. With new additions of certain songs, to verie late deuised notes, not commonly knowen, nor vsed heretofore, by Clement Robinson, and diuers others (London, 1585). The first edition of the latter miscellany may also have been printed in the 1570s; the STC dates two unbound bifolia of the volume to 1575 (STC 21104.5). 
Sternhold's Certayne Psalmes and the Certayne chapters out of the Prouerbs of Salomon (which he erroneously attributed to Sternhold), both of which Seres had printed during Edward's reign. ${ }^{64}$ In 1559, John Day was fined for printing psalms "without lycense and contrary to the orders of this howse," but he received a privilege later that year that seems to have authorized his printing of the psalms and then it was Seres's turn to pay a "fine for pryntynge of psalmes Contrary to the orders of this howse." ${ }^{65}$ The psalters from these years do not survive, so we have no way of knowing whether they were versions of Sternhold and Hopkins and, if they were, which psalms they included. But Day seems to have established his right to the Sternhold and Hopkins psalter and would go on to produce four different versions of the psalter between 1560 and 1562 before releasing the Whole Book of Psalms in 1562. ${ }^{66}$ During both Edward's and Elizabeth's reigns, Day was known for printing reformed Protestant works, including those of Hugh Latimer, John Calvin, and Thomas Norton, but he, like Jean Crespin, would solidify his image as a Protestant printer by producing a martyrology: in his case, John Foxe's Actes and Monuments, which first appeared in $1553 .{ }^{67}$ Day's versions of the metrical psalter may have been intended as a quick source of funds, since most of his printing operation was tied up in the production of Foxe's elaborate volume, but he also seems to have dedicated some thought to the planning of the psalters, commissioning writers like John Hopkins and Thomas Norton to compose additional psalms and compiling psalms, prayers, and introductory materials from a wide variety of continental and English sources. ${ }^{68}$

Day retains Whittingham's revised versions of the psalms by Sternhold and Hopkins as well as the claim on the title page that they have been "conferred with the Hebrewe," but he does not include Whittingham's explanation of his scholarly methodology, and after 1561 he removes the note in the title

64. Edward Arber, ed., A Transcript of the Registers of the Company of the Stationers of London: 1554-1640 (London: 1894). 1:95; Certayne Psalmes select out of the Psalter of Dauid, and drawen into Englyshe metre, wyth notes to euery Psalme in iiij. parts to synge, by F. S., (London, 1553); Certayne chapters.

65. Arber, 1:124; Arber, 2:61-62; Arber, 1:158. See Leaver, 242; Elizabeth Evenden, Patents, Pictures and Patronage: John Day and the Tudor Book Trade (Burlington, VT: Ashgate, 2008), 49.

66. Quitslund, 201.

67. See Christopher Lewis Oastler, John Day, the Elizabethan Printer (Oxford, Oxford Bibliographic Society, 1975); Evenden, Patents.

68. Quitslund, 210. For the sources of non-psalm material in the 1562 version, see Quitslund's Appendix B. 
indicating that the psalms have been "corrected, as the se[n]se of the prophet requireth." ${ }^{69}$ Much of the scholarly apparatus-the prose arguments, verse numbers, and select marginal glosses-also remains in the 1562 psalter. But, with the removal of the Whittingham preface and the title-page language about revision, the claim to linguistic precision seems to have been subordinated. It is replaced by an emphasis on the uses of the psalms, since Day adds a "Short introduction to the Science of Musicke" and a treatise of Athanasius on how to apply the psalms to one's life. ${ }^{70}$ All of this new material bolsters the title-page statement that the psalter is "very mete to be vsed of all sortes of people priuately for their solace \& comfort, laying apart all vngodly songes and ballades, which tende only to the norishing of vyce, and corrupting of youth." ${ }^{71}$ As in Coverdale's volume, the psalms are presented as sources of comfort and as compelling musical works that can compete with secular songs and ballads. In addition, the emphasis on private, ordinary usage is striking since Sternhold and Hopkins later became known as a liturgical volume.

The titles and formats of the psalters Day produced in the 1560s suggest that the volume was only gradually taken up by the Elizabethan church. Quitslund has corrected the ubiquitous misconception that the claim on the 1562 title page, that the volume was "faithfully perused and allowed according to thordre appointed in the Quenes Maiesties iniunction," indicates that the psalms were permitted for congregational singing, pointing out that "the title page refers not to the $49^{\text {th }}$ Injunction concerning ecclesiastical music, but to the $51^{\text {st }}$, which established a series of authorities for licensing books before publication." ${ }^{\prime 2}$ There would be no allusion to public singing until 1566, when

69. Foure score and seuen Psalmes of Dauid in English mitre by Thomas Sterneholde and others: conferred with the Hebrewe, ad in certeine places corrected, as the se[n]se of the prophet requireth. Whereunto are added the Songe of Simeon, the ten Commandments and the Lords Prayer (London, 1561); Zim, 142. 70. The whole booke of Psalmes collected into Englysh metre by T. Starnhold, I. Hopkins, \& others, conferred with the Ebrue, with aptnotes to synge the $[m]$ with al; faithfully perused and alowedaccording to thordre appointed in the Quenes Maiesties iniunctions; very mete to be vsed of all sortes of people priuately for their solace \& comfort, laying apart all vngodly songes and ballades, which tendeonly to the norishing of vyce, and corrupting of youth (London, 1562).

71. In his first chapter, Hamlin provides evidence that Sternhold and Hopkins was in fact used by all sorts of people. Hamlin, 19-50.

72. Quitslund, 201; Walter Howard Frere, ed., Visitation Articles and Injunctions of the Period of the Reformation (New York: Longman, 1910), 5:3. 
the phrase, "Newlye set foorth and allowed to bee soong of the people together, in churches, before and after mor[n]ing and euening prayer: as also before and after the sermon, and moreouer in priuate houses," was added to the title page. ${ }^{73}$ As seventeenth-century reformation historian Peter Heylyn noted in 1660, "No such Allowance" has been "any where found, by such as have been most Industrious, and concerned in the search thereof." ${ }^{74}$ But the print history of the psalter also suggests that there may have been a change in the use of the volume between the original printing in 1562 and the addition to the title page in 1566, whether the change was instigated by official endorsement of the psalter or not. Ian Green, taking a long view of the psalter's history, has argued that Sternhold and Hopkins was printed in the largest formats at the outset of its publication and that the psalters were often printed in the same formats as the Books of Common Prayer and Bibles printed in a given year so that they could be bound in with these works for liturgical use. ${ }^{75}$ Close attention to the editions produced in the 1560s and early 1570s, however, reveals that Day may not have initially marketed the book for liturgical use. Between 1562 and 1564, Day produced octavo and quarto versions of The whole book of Psalmes. ${ }^{76} \mathrm{He}$ printed only two folios of the psalter between 1562 and 1572: one in 1565 and another in 1567.77 Moreover, between 1562 and 1572, the formats of the psalter only match that of the Book of Common Prayer in the years 1564-66; in each of these years, one of the books was produced in two formats, so the overlap may be coincidental. ${ }^{78}$ In 1566, for example, both the psalter and the Book of Common Prayer were

73. The vvhole boke of psalmes, collected into English metre by Thomas Sternhold, Iohn Hopkins, and others: conferred with the Ebrue, with aptnotes to syng them wyth all.; Newlye set foorth and allowed to bee soong of the people together, in churches, before and after moring and eueningprayer: as also before and after the sermon, and moreouer in priuate houses, for their godlye solace and comfort, laying apart all vngodly songes andbalades, which tend onely to the nourishing of vice, and corrupting of youth (London, 1566).

74. Peter Heylyn, Ecclesia restaurata, or, The history of the reformation of the Church of England (London, 1660), 131.

75. Green, 512-14.

76. STC 2430, 2430.2, 2432. He also produced an octavo version of the first part of the psalter in 1564, STC 2433.

77. STC 2434, 2438.

78. See STC 2432, 16296, 16296.3 (1564); STC 2434, 2435, 16296.5 (1565); STC 2437, 16297, 16297.5 (1566). 
produced in quarto, but the Book of Common Prayer and the Great Bible were also produced in folio format. Thus, the liturgical use of Sternhold and Hopkins becomes more likely in the mid-1560s, when the title-page refers to public singing and the first folio versions were printed, but the variety of formats printed during this period and the mismatch between the format of the psalter and the Book of Common Prayer suggest that Day did not market the volume primarily for liturgical use. ${ }^{79}$

Whether or not the earliest versions of Day's psalter were taken up by the English Church, he certainly contributed to the popularization of a view of the psalms that would prove formative for English devotional poetry. For, alongside traces of the Genevan connection to the hebraica veritas, the 1562 psalter preserves and even amplifies the insistent attribution visible in the earlier psalters. John Hopkins's name is added to the title page beside Sternhold's, and, once more, the author of each psalm is specified with initials next to the psalm number and title. In addition, a slight modification in the titles of the hymns included before the psalms in the 1562 volume stresses the fact that they, too, were composed by individual writers. Two of the songs, for example, are taken from the Wesel version of the psalter, but their names have been changed from "Benedictus in Metre" and "Magnificat" to "The Song of Zacharias, called Benedictus" and "The songe of Blessed Mary, called Magnificat." 0 These changes make the titles more consistent with those of the other songs, which include "The songe of the thre Children praising God," "The Song of Simeon," "The Crede of Athanasius," "The Lamentation of a Sinner," and, of course, the "Psalms of David." ${ }^{\text {1 }}$ The persistent use of genitives draws attention to the particular history of these songs and the particular people who wrote and sang them. These possessive titles suggest that the understanding of English psalmody often attributed to Philip Sidney is already tacitly acknowledged in Sternhold and Hopkins: the idea, that is, that David's poetic enterprise is comparable to the work of contemporary English poets and that his example therefore sanctions the poetic enterprise. Day's 1562 psalter, then, combines the two strains of psalmody identified in Coverdale and Crowley: the psalter advertises

79. Quitslund surveys the scanty evidence about Sternhold and Hopkins use in the 1560s in the final chapter of her book. Temperley, Green, and Quitslund point out school statutes requiring children to sing metrical psalms contributed to their spread. Temperley, 1:63, Green, 510, Quitslund, 241.

80. Psalmes of David in Metre; Whole book, A7r, A8v.

81. Whole Book, A5v, B1r, B2r, B5r. 
its scholarly fidelity to the scope as well as the language of the psalms without concealing the artistic work performed by the seven poets who contributed to the volume. Although the particular style of the Sternhold and Hopkins psalter would soon become outmoded and would be subject to repeated mockery in the seventeenth century, many of the English poets who denigrated the psalter were indebted to it for its understanding of sacred poetry. Although the contributors to Sternhold and Hopkins did not go so far as John Milton in describing the poetic office as "of power beside the office of a pulpit," they paved the way for his belief, shared by other seventeenth-century English poets, that poetic fame and fidelity to the Scripture are reconcilable since a composition can derive its authority from both its human and its divine origins. ${ }^{82}$

82. John Milton, Complete Poems and Major Prose, ed. Merritt Y. Hughes (Indianapolis: Hackett, 1957), 669. 
